\title{
A Delphi study to explore the adoption of servitization in UK companies
}

\author{
Tim Baines, \\ Aston Centre for Servitization Research and Practice, Aston Business \\ School, Birmingham, UK \\ and \\ Victor Guang Shi \\ Advanced Manufacturing Research Centre, Sheffield University.
}

\section{Correspondence to:}

Tim Baines

Professor of Operations Strategy

Aston Business School,

Birmingham

B4 7ET

t.baines@aston.ac.uk

01212043051 


\title{
A Delphi study to explore the adoption of servitization in UK
} companies

\begin{abstract}
This paper explores and rationalises the process of servitization adoption across manufacturing firms. A Delphi research methodology has been applied to capture evidence and opinion from 33 senior executives, in 28 different sized organisations, from a cross section of British industry. The findings focus on five areas: (1) servitization and advanced services, (2) transformation: stimulus, drivers and organisational change, (3) impact on the customer and manufacturer, (4) enablers and inhibitors and (5) potential for business and the economy. Six findings are presented and collectively these contribute to our understanding of the broader change management processes that transform manufacturers to compete through advanced services.
\end{abstract}

\section{INTRODUCTION}

Developed economies continue to debate intensely the rights and wrongs of favouring a service sector over manufacturing, and the desirable balance in an economy. But arguments are often based on shaky foundations; original equipment manufacturers (OEMs) are themselves transforming into services providers and so blurring our perspective. The business community frequently struggles to give a name to this transformation, but the research has coalesced around the term 'Servitization'. This term originates in marketing research of the 1980s and 90s, and is gaining broad acceptance amongst engineering and business scholars (Baines et al., 2007). An appreciation of the organisational changes required to successfully servitize is steadily growing (see for example; Oliva and Kallenberg, 2003; Davies, 2004; Brax, 2005; Davies et al., 2006; Gebauer et al., 2008; Datta and Roy, 2011; Bastl et al., 2012; and Baines and Lightfoot, 2013). However, research that focuses on the processes of change management for servitization is more elusive.

Understanding the organisations that are servitizing and what they offer in markets is foundational to the transformation debate. Work to classify service offerings as models, matrices and frameworks is provided by a range of authors (e.g.: Bowen et al., 1989; Silvestro, 1992; Collier and Meyer, 1998; and Oliver and Kallenberg, 2003). Authors such as Vandermerve and Rada (1988); Galbraith (2002); Brax (2005); Slack (2005); Martinez et al., (2010) and Maull et al., (2013) explore motives, processes, ideas and challenges around changes to business unit structure supporting servitization. In complement, Wise and Baumgartner (1999); Mathieu (2001); Malleret (2006) and Baines et al., (2009b) all describe benefits companies have realised from following a servitization strategy. The hurdles faced by companies, and perhaps more critically how these have been addressed, has been explored by a range of researchers including Vandermerwe et al., (1989); Mathieu (2001) and Reinhart and Ulaga (2008). By contrast, the economic implications across businesses and economies has only been addressed by a few researchers, most notably Sawhney et al., (2003) and Neely (2009). Collectively the majority of these exiting studies have sought to conceptualise and contextualise servitization adoption, and tend to rely on data from two-three organisations that are recognised practice leaders.

The transformation debate can therefore benefit from a more extensive and evidenced insight into industrial practice. A review across previous work (section 2,Table 1) points to five specific research questions; (1) What types of organisations are servitizing, what services are they offering, and what are the features of these?, (2) How have early adopters come to servitization, what factors have driven customers to adopt services offered by OEMs, what factors have driven OEMs to offer these, and how have OEMs begun to change to realise these opportunities?, (3) What are the actual benefits that both customers and manufacturers have realised, how well did these align with their drivers, and what other benefits were realised?, (4) What factors are inhibiting and enabling the adoption of these services within both customers and OEMs?, and (5) What is the net benefit of servitization to business and an economy?

This study has set out to address these questions. A Delphi research methodology has been applied to capture evidence and opinion from 33 senior executives, in 28 different sized organisations, from a cross section of British industry. It is these experiences that we have brought forward in this paper, providing examples and quotations throughout that demonstrate that the findings we put forward are formed on evidence from industry. The findings resulting from this study fall into five topics: (1) servitization and advanced services, (2) transformation: 
stimulus, drivers and organisational change, (3) impact on the customer and manufacturer, (4) enablers and inhibitors and (5) potential for business and the economy. The following paper is structured around these, and summarises evidence in each as findings for future work.

\section{RESEARCH CONTEXT}

There is a growing body of research exploring the process of servitization adoption. Table 1 summarises the literature emerging in this field, and how it tends to contribute to the what, how, why, when and outcome of a servitization transformation. By then assessing the contributions in each category the research questions underpinning this study have been established. Given below is a summary of the literature considered in via this process and the resultant questions.

An opening question across much of this literature is what form of change is taking place? Fischer et al., (2010), for example, suggest firms can simultaneously exploit and explore service capabilities by developing system integration, operational services and business consulting, and carry out explorative activities through spatial expansion and reconfiguration along the adjacent customer activity chain.

Others suggest firms design a portfolio of services to target customers' varying needs (Cohen et al., 2006), from selling systems to selling solutions (Davies et al., 2007). Other descriptions of this change adopt a life cycle based approach of offering value-sharing contracts to gain from efficiency savings during the operational life of the contract (Davies, 2004), applying different business models for the same asset at various stages of its life cycle (Cohen et al., 2006), and transforming from product-based to use and outcome-based services (Davies, 2004).

In this model, manufacturers are transformed into outsourcing partners (Fischer et al., 2009). For example, BAE Systems takes entire responsibility for providing the UK Ministry of Defence (MOD) with Tornado aircraft with depth support and upgrades (Purchase et al., 2011). In the commercial construction sector, contractors require the use, rather than ownership, of functioning and available tools; Hilti, a power tool manufacturer, responds to this needs by offering "tool use" instead of tools themselves (Johnson and Christensen, 2008). In the chemical industry, $\mathrm{ICI}$ Explosives adopted a new business concept by selling "rock on the ground" to the customer, rather than explosives (Martinez and Turner, 2011).

Although much progress has been made on rationalising these offerings, there is still an opportunity to gain greater insight from the actions of practitioners. Therefore our first research question is:

(Q1) What types of organisations are servitizing, what services are they offering, and what are the features of these?

Having an improved understanding of the phenomenon then begs questions as to how it has come about. Ulaga and Reinartz (2011) have explored how firms have fundamentally changed their business models from promise to perform a deed, to performance related to an asset's productivity. Literature suggests early adopters of servitization are influenced by varying degrees of external pressures such as competitors from low wage countries (Brecher et al., 2012, and Baines and Lightfoot, 2013), political and macroeconomic policies for relocation of industries, and transformation of national economies (Baines et al., 2009).

Others suggest endogenous factors such as the need for customers and OEMs to: increase operational efficiency (Koudal, 2006, and Smith et al., 2012); defend their strategic position (Cohen et al., 2006); and grow and simultaneously pre-empt competitions (Fischer et al., 2008). Research also suggests cognitive factors such as entrepreneurial leaderships within the organization (Fligstein, 1991); whereas a manufacturing person will tend to see organizational problems in production terms and a marketing person will view size and extent of the market as critical to the organization's survival, an advanced product services person would see customer 'pains' as critical to the organization's structural and infrastructural decisions (Fligstein, 1991, Baines and Lightfoot, 2013).

Although earlier research has made progress in identifying various external and internal drivers on servitization adoption, there are still gaps to be filled to understand the extent to which these drivers have impact on OEMs. Therefore our second research question is: 
(Q2) How have early adopters come to servitization, what factors have driven customers to adopt services offered by OEMs, what factors have driven OEMs to offer these, and how have OEMs begun to change to realise these opportunities?

A logical next step is to question the benefits of servitization. Much has now been written on how servitization can be used to 'pre-empt' competitors by proactively expanding service capacity to shape, rather than react to, the demand for a firm's products (Hayes, 2005). The longer the life of cumulative installed capital goods currently used by customers, the more attractive service opportunities will be and these services provide a more stable source of revenue than the volatile product business (Cohen et al., 2006). A services business model also creates competitive advantage by enabling the manufacturer to gain a deep understanding of customers' technologies, processes, and plans, which rivals cannot easily acquire (Cohen et al., 2006). Servitization also increases the customer's switching costs (Shankar et al., 2009) through longer contract and collaborative processes.

The benefits of servitization are however not universally agreed. While some suggest significant improvements have been made in terms of increased profit margins (Baines and Lightfoot, 2013), a stable income decoupled from market turbulence (Yorozu and Shi, 2014), and environmental benefits (Sakao and Lindahl, 2009, and Shi et al., 2012), others argue that, despite significant investment, returns do not match managers' expectations (Gebauer and Fleisch, 2007). Therefore, our third research question is:

(Q3) What are the actual benefits that both customers and manufacturers have realised, how well did these align with their drivers, and what other benefits were realised?

Realisation of these benefits will be impacted by enablers and inhibitors. Previous examinations of enablers and inhibitors of servitization have been somewhat inconclusive. For example, some suggest manufacturers are enabled by their ability to carry out incremental change (Fischer et al., 2010), or to incrementally leverage existing resources and develop capabilities (Ulaga and Reinartz, 2011). Others suggest a more radical approach to organizational change is key, and argue that incremental change would create conflicts that can inhibit servitization (Brax, 2005). Therefore, our fourth question is:

(Q4) What factors are inhibiting and enabling the adoption of these services within both customers and OEMs?

Ultimately the adoption of servitization should have a net benefit to an economy. The manufacturing industry has a multiplier effect on inter-industrial growth; it is the main driver of value creation in other industries and of employment (Brecher et al., 2012). Recognition of the net benefit of servitization can help to accelerate diffusion across various industrial sectors, providing a 'best practice' framework to guide organizations in various sizes, and enabling better policies to be designed to enhance multi-level organizational collaboration (Purchase et al., 2011). Therefore, our fifth research question is:

(Q5) What is the net benefit of servitization to business and an economy?

Collectively these research questions come together as a preliminary research agenda for the adoption of servitization. Addressing these has been the purpose of the study presented in this paper.

\section{RESEARCH DESIGN}

\section{Choice of methodology}

Servitization is a challenging topic to study; nuances can be easily misunderstood and often require careful explanation. Conventional survey techniques (where respondents complete questionnaires remotely and in isolation) fail to give sufficient insight into practice, and yet in-depth case studies are so resource intensive that they rarely deliver reliable generic results. A technique was therefore sought that combined the strengths of these two approaches, and so a Delphi method was identified and selected for this study.

The Delphi method is a systematic and interactive research technique for obtaining the judgment of a panel of independent experts on a specific topic (Hallowell and Gambatese, 2010). This technique was developed in the 1950 s at the Rand Corporation by Helmer and Dalkey, and seeks to reach consensus among participants about a complex topic through a survey consisting of a series of rounds (Amal, 2005; Cho et al., 1991; McClave and Benson, 1988; Waissbluth and De Gortari, 1990; Fontana and Frey, 1994). 
This methodology has been applied in many fields (Miller, 1993). The validity and reliability of findings is achieved through the interaction and combination of expert judgments (Bardecki, 1984; Parente, Anderson, Myers, and O'Brin, 1984; Amal, 2005). In particular, the Delphi method is well suited as a research instrument when there is incomplete knowledge about a problem or phenomenon (Ferri, et al., 2006). It works especially well when the goal is to improve understanding and when the problem does not lend itself to precise analytical techniques (Hallowell and Gambatese, 2010).

There are three major components of conventional Delphi research (Amal, 2005). These components are: (1) creating a panel of anonymous experts on an issue of concern, (2) conducting a series of rounds by using questionnaires to get expert opinions on that issue, and (3) sharing feedback of respondents with all participants (Bardecki, 1984; Masser and Foley, 1987). These three steps were applied in our study as follows.

\section{Establishing the expert panel}

The most important facet of a panel member is its level of expertise. Hallowell and Gambatese (2010) suggest that experts must satisfy at least four criteria in the topics related to the research. Similarly the number of panellists is critical. De Loe (1995) suggests ten to fifty as an optimal number of panellists to produce valid results; Miller (1993) argues that thirty responses will generate sufficient information regarding an issue investigated; while Rowe and Wright 1999 indicate that the size of such panels have ranged in peer-reviewed studies from a low of three members to a high of 80 .

Following these guidelines, our approach was to first identify suitable experts. To qualify as a panellist, individuals were sought which: (1) were associated with an organisation either delivering or consuming advanced services (manufacturer or customer); (2) had themselves been involved with delivering such services; (3) had knowledge and experience of a breadth of functions; and (4) felt that they had some authority on this topic. A search and selection process then followed, and a panel of 33 experts came forwards from 28 organisations based in the UK (see table 2). These were all senior executives and provided insights across the sectors of health, infrastructure, transport and energy.

\section{Research questions and questionnaire design}

A data collection protocol was developed around the research questions developed in section 2. Data was sought for: (1) servitization and advanced services; (2) transformation: stimulus, drivers and organisational change; (3) impact on the customer and manufacturer; (4) enablers and inhibitors; and (5) potential for business and the economy. These questions were then complied into a questionnaire which was piloted with senior executives from Xerox. Piloting followed guidelines given by Hallowell and Gambatese (2010). This led to refinements in the way questions were posed to ensure that the questionnaire elicited the desired data, and was not too demanding on participants' time to complete.

The questionnaire was then distributed to all panellists. Responses were captured through semi-structured interviews with the researchers asking the questions and recording answers. Two researchers were present at each interview, and answers were captured by both audio recording and note-taking. Each panel member was interviewed for between one and three hours, and the conversations were recorded and transcribed.

\section{Process for sharing feedback}

As mentioned above, the feedback process is the mechanism for informing panel members of the opinions of their anonymous counterparts (Hallowell and Gambatese, 2010). Feedback is intended to take place after each round of surveys has been completed. Accuracy is expected to increase over rounds because of the repetition of judgments and group pressures for conformity despite the anonymity of responses (Amal, 2005). Woudenberg (1991) suggests two to ten as an appropriate number of rounds, while Hallowell and Gambatese, (2010) note that most peer-reviewed Delphi studies maintain the number of rounds to be between two and six. Indeed, Dalkey et al., 1970 suggest that the Delphi results are most accurate after round two and become less accurate as a result of additional rounds. Therefore, in this research the target was three rounds of feedback, with a caveat that this would be extended if responses failed to converge.

After each round, an anonymous summary of the experts' input was compiled and presented back to the panellists. They were then encouraged to review the anonymous opinion of the other panellists and consider revising their previous response. The purpose of this process was to improve the precision of the responses and foster a group consensus. 


\section{Execution and results}

Throughout this study the research team partnered with Xerox. This organisation has a long heritage of delivering advanced services coupled to its equipment, and this year generated over half of its revenue from such services. In celebration of this achievement Xerox staff helped with the design and piloting of the questionnaire to ensure that the outcomes were directly relevant to industry. In true partnership style, the Xerox team respected fully the autonomy and independence of the research team

In all, 33 experts from 28 organisations participated between November 2012 and May 2013. In each case senior managers were interviewed, and their responses recorded and transcribed. Three rounds of interviewing were carried out. The first captured the bulk of the data, which the research team then compiled, and clustered around key themes. This was then fed back to the experts, as a second round, who then responded with refinements and additional data. A third round was then executed as a final check for anomalies and convergence of findings.

\section{FINDINGS DEVELOPED THROUGH THE DELPHI STUDY}

The results from the Delphi study led us to refine our knowledge about (1) the adoption of servitization in the UK, (2) the transformation processes being followed, (3) benefits being realised, and (4) enablers and inhibitors affecting OEMs. Each of these topics are now discussed individually and summarised as a key finding.

\subsection{SERVITIZATION ADOPTION}

At the outset we sought to understand how OEMs are choosing to compete through services. What types of organisations are servitizing? What services are they offering? What are the features of these? The following picture emerged from the study.

\section{Technology innovators as services providers}

Manufacturers who are advanced in servitization rarely want to associate themselves with 'manufacturing' or 'production'. Instead they prefer to be known as 'service partners' or 'providers', and yet these phrases are themselves are inadequate. These organisations are services providers who are also technology innovators. These innovation capabilities manifest as research, design and production processes that result in intellectual property that differentiates these organisations from more conventional services providers (Windahl et al., 2004; Neu and Brown, 2005; and Sumi and Kitatani, 2014).

These technology-innovators exhibit a capability to actually create a product (or asset), put it in the field, manage it, maintain it, repair it, improve it, and dispose of it at end of life. Alstom Transport, for instance, sees itself as holding the 'technical know-how and know-why' that enables a more exclusive service, and Xerox refers to itself as services driven, technology enabled. For customers of Xerox, such as British Airways, the value of Xerox's technology innovation capability is its ability to 'understand, and redesign the technology and make sure it's appropriate for the application and help improve the efficiency and effectiveness of processes within which the technology sits'.

\section{Servitization though advanced services}

Many types of organisations are engaged in delivering services. This study has focused on those organisations that have been engaged historically with Original Equipment Manufacturer (OEM), and that have changed their business models from being production-centric to services-focused. These are technology-innovators rather than technology-integrators. Yet, these organisations can implement various servitization strategies, for instance they can extend their provision of intermediate services (e.g. condition monitoring, breakdown, repair), or move to engage in a corporate takeover of a conventional services provider (e.g. consultants, accountants, training firms).

Prevailing across this study however was a move to delivering 'advanced services'. Such a transformation was seen to be fundamental to a servitization journey, with base and intermediate services forming part of their portfolio. Xerox's 'Managed Print Services' is an excellent example of such an advanced service. Rather than simply selling printing equipment, the company offer 'document solutions' to customers. This means that for a typical customer, such as BA, Xerox provides: 
'Project management, implementation of all the new technology or the new workflow, through to providing the hardware. They're managing third parties that they're interfacing with, companies like the Royal Mail and courier companies on our behalf.'

There are various names given to these advanced services. Terms include availability contracting, performance contracting, managed services and solutions. However the outcome of these contracts is, invariably, a capability for a customer to perform a business function or process. This is distinct from more conventional services where the outcome is product ownership and maintenance of an asset's condition (Mont, 2002; Tukker 2004; and Gebauer et al., 2013).

\section{Features coupled to advanced services.}

Advanced services imply a redefinition of the boundary between those activities that are carried out by the customer and those performed by the manufacturer. Confusion arises around the definition of advanced services because particular contracting features are often coupled. The companies in this study described four key features; the first three of these are relatively widespread:

- Pay-for-use revenue payment: pay-per-click, pay-as-you-go, power-by-the-hour etc. are all terms used commonly to refer to advanced services. For instance, in its contract with Xerox, Islington Borough Council receives a 'click charge' each time a document goes through a machine.

- Long-term contracts: Contracts of less than two years are rare. For example, The Heart of England NHS Foundation Trust has a ten year contract for its pathology laboratory facility, while in power generation, GDF Suez will enter into contracts of 20 to 25 years.

- Risk management: The provider takes on the responsibility for ensuring asset availability, condition and performance. An Alstom train can incur penalties of $£ 600$ for every minute of delay in arriving at a station if the fault is with the OEM.

Advanced services contracts also increasingly feature commitment to on-going process improvement and cost saving. This is illustrated by BA's tendering processes:

'We could just have employed someone to deliver letters around our business and that's it - and there are plenty of companies out there who can do that -but it's the one that has the capabilities and also the vision to start saying 'well, do you need to physically deliver that letter, what about scanning it in as soon as we receive it and pushing it through a digital workflow? What about pushing into a digital mailroom, so that your chief executive can read his letters whether he's in his office in London or whether he's over in Spain or if he's in

Chicago?'

When these four features are coupled with the principle of delivering a capability, contracts become sophisticated and demanding. Many existing contracts are relatively large. For instance, MAN Truck and Bus UK has 10,000 vehicles under contract at present, and expects this to grow by $50 \%$ over the next three to five years, to represent f200million of business. The Heart of England NHS Foundation Trust's five year contract in its pathology laboratory is valued at $\mathrm{f} 20 \mathrm{M}$ per year.

In summary, through this study we now understand about servitization adoption that:

Finding 1: Servitization is seen in practice as technology-innovators (original equipment manufacturers) shifting from simply supplying products, to delivering the capability (advanced services) that their products enable, and then using their own design and manufacturing knowledge and capacity to continually improve this capability. These advanced services are commonly coupled with features of (1) pay-for-use, (2) long-term contracts, (3) risk management, and (4) commitments to ongoing process improvement.

\subsection{TRANSFORMATION: STIMULUS, DRIVERS AND ORGANISATIONAL CHANGE}

Having established the services being offered, their features and characteristics, we sought to understand what had caused OEMs to develop services strategies: How had early adopters come to servitization? What factors 
drove customers to adopt advanced services offered by OEMs? What factors drove OEMs to offer these advanced services? How had OEMs begun to change their organisations to realise these opportunities?

\section{Stimulus of services strategies}

Some OEMs were very much encouraged to move to services by their customers. For MAN Truck and Bus UK the driver was the 2006 Heavy Duty Truck Comparison in which the company was placed seventh out of seven for customer service; GKN undertook an initiative to look at what its future customers wanted; and Selex Electronic Systems also moved to services in response to customer demand.

Such market pull also occurred through indirect routes; previous UK governments have helped to stimulate servitization through large infrastructure projects where they sought to encourage private finance. Alstom Transport illustrates how this occurred;

'Prior to privatization national operators, like British Rail and London Underground, carried out their own maintenance. They bought their own rolling stock, and in some cases with British Rail they made their own. When private finance came into it, it became a matter of risk management, and a matter of the banks and the finance companies saying, 'you want us to provide money, so we want to make sure that the asset remains in tip-top condition and that there isn't any potential compromise to the life of the asset'. To do that, they sought the OEM to be involved.'

OEMs have also encouraged their customers into servitization; Rolls-Royce for instance came up with proposals which were put to its customers as innovative ways of doing things, but which also achieve the objectives of keeping out other players which were emerging in the marketplace. Ultimately no one community (OEMs or customers) appears to have been dominant; the origins are summarised by British Airways as an interplay of customers seeing an opportunity to manage costs, and OEMs realising that they can't just rely on producing hardware and that they need to look at the soft services as well.

\section{Initial drivers of servitization}

Understanding the reasons underpinning the early adoption is fraught with difficulty. The benefits realised by a host can inspire a level of 'post-rationalisation' of the decision, and so caution was applied when inquiring about these. Subsequently two categories of factors emerged;

- Defensive (reasons) : Anticipating a threat and preparing to respond

- Offensive (reasons) : Intended for, or used in, attack

The reasons given by both OEMs and their customers for the adoption of advanced services can be set against these categories (Table 3). Although this table shows a relatively even distribution across categories, invariably the actions of both OEMs and their customers were largely for defensive reasons.

The OEMs studied largely servitized to defend their commercial viability, in particular to prevent competitors from gaining a foothold in their markets. Alstom Power illustrates this;

'... once a third party's into one of our machines here, they can possibly attack around the world and that's what we try and stop with these contracts'.

On occasion, OEMs also reported choosing services to assert their capabilities in the market. In particular, helping to gain market acceptance for new innovations that would lead to business growth.

Customers chose to deal with servitized manufacturers to improve financial, risk and asset management. Desires for cost saving were prevalent. British Airways, for example, sought cost savings and improvements in efficiency; the Heart of England NHS Foundation Trust targeted economic drivers; and typical customers of Selex Electronic Systems desired a year-on-year improvement in cost reduction. Other customers sought to transfer capital expenditure to variable revenue payments (carrying these on the profit and loss account rather than the balance sheet). Hoyer, for instance, wanted a pay-as-you-go system where costs were 'per mile' driven, so that its overall contract costs were more predictable.

Some customers also adopted manufacturers' services to drive focus and investment. For instance, British Airways saw these services as taking a lot of its 'pain' away and enabling a focus on the core business of being an 
airline. Similarly Hoyer sees itself as an expert transport company, whereas the management of workshops is not a core competency.

\section{Organisational change within the OEM}

Both customer and OEMs have undergone significant organisational change through the adoption and delivery of advanced services. In this study we only sought to identify those at the forefront of executives' minds. Most prevalent were changes for staff and organisational culture. For instance, MAN Truck and Bus UK had to instigate a complete cultural change, coupled with changes to organisational structure, while GKN created a dedicated organisation with particular service skills.

It is often necessary to engage partners to enable the delivery of the complete set of services demanded by the customer (Chesbrough, 2010; and Auguste et al., 2006). For example Xerox UK interfaces with companies like the Royal Mail and courier companies on behalf of its customers. There is also a need to adopt new information and communication technologies to report on the location, condition and use of product in the field. This facilitates management information (MI) goes back to the customer, and provides transparency and a firm basis for joint conversation around service enhancements.

Change management is wrought with challenges, many of which are not particular to servitization. Transformations are not achieved overnight. Many of the organisations we have studied have been on a servitization journey for at least a decade - such as GKN which started its transformation 10 years ago. For others this has been shorter; MAN Truck and Bus UK rose from seventh position to second place in the Heavy Duty Truck Comparison in the space of four years.

In summary, through this study we now understand about the transformation process that:

Finding 2: Servitization has been stimulated through an interplay of actions by both OEMs and their customers. Early adopters were driven largely by defensive reasons to improve commercial viability, and improvements to financial, risk, and asset management within their businesses. It is also driven, to a lesser extent by offensive improvements to focus and market competitiveness. Delivery of advanced services has, however, demanded significant changes to the culture, technologies, organisational structure and processes.

\subsection{SERVICES STRATEGY BENEFITS}

The initial stimulus and drivers are helpful in understanding the early adoption of advanced services. More useful still is to understand the actual benefits that both customers and manufacturers have realised. How well did these align with their drivers? What other benefits were realised? What draw backs have become apparent?

\section{Benefits; realisation of initial drivers}

The companies we studied realised the benefits they sought. Table 3 expresses the 'initial drivers' that helped to explain the particular motives for both customers and OEMs to servitize, and Table 4 shows what they achieved. As expected those organisations featured in the study recorded success (the criterion for their inclusion) nevertheless it is reassuring that their strategies realised the specific results they sought. For example, against the customer drivers given in Table 1 the following achievements were recorded;

'We've handed over that activity to Xerox, and now we just consume on a great pricing code' [British Telecom] 'We put in a managed print service to take a million pounds off the cost of printing a year, and we did it' [University of Nottingham]

'Investment in terms of the rolling stock and the infrastructure has been huge [Alstom Transport].

The OEMs spoke of equivalent experiences against their drivers;

'If we had not engaged as a service organisation this company would be dead' [MAN Truck and Bus UK]

'Nobody else can run this equipment more efficiently than we can, nobody else can provide the parts and the correct service provision better than we can, so it's a very unique position' [Finning UK] 
'Right now we've got several hundred million pounds' worth of contract agreements or business ... it is very sizeable and far beyond just supplying a part. [GKN]

\section{Benefits; beyond initial drivers}

The benefits of advanced services have exceeded the original motivations for their adoption. Table 4 shows how this picture has developed, beyond the early drivers of Table 3, illustrating what servitization has enabled in these organisations.

For OEMs there has been a range of significant benefits to growth in terms of customer numbers, markets, and new market entrants. Growth with existing customers has been achieved through improved customer intimacy brought about by closer and stronger relationships. Moreover, new market opportunities have been created. For example, Rolls-Royce services such as TotalCare have supported the creation of low-cost airline operators because the emphasis on maintaining the product is with the OEMs. There have also been benefits to product development, as exemplified by MAN Truck and Bus UK;

'The truck is a mobile RandD centre...I've now got a ten billion kilometre database of all categories of transport where I can show quite clearly what our vehicles cost to operate'.

Similarly, Xerox is now managing over 1 million devices, half of which are those of competitors, so providing incredible insight into the technical features and performance of products in the market place.

For customers, there have been improvements in safety and environmental sustainability. MAN Truck and Bus UK reported that the services it provided improved fuel consumption by at least $10 \%$ and reduced $\mathrm{CO} 2$ emissions by $10-15 \%$. The University of Nottingham has seen its document management systems as about $70 \%$ greener. In addition, these services have enabled structural change that was elusive within the customer.

From an offensive perspective, customers have also improved their own competitiveness through improved service quality to their own customers. For instance Alstom Transport described how the West Coast Mainline was actually smaller than the East Coast when Virgin (and partners) took it over. Today it is twice the size of the East Coast because of the improved standards of rail travel: there are now up to 32 million passengers a year travelling on it.

\section{Quantifying impact}

Our intention has been to translate these benefits into quantifiable business impact. The four quadrants in Table 5 indicate how the adoption of services has impacted business performance. For customers, 'cost reductions attributed to the adoption of services from OEMs' reflects their desired improvements in business efficiencies, while 'growth of their own services through improved service performance' helps to indicate improvements in their own business performance attributable to the services of the manufacturer. For OEMs, a move away from relying only on product sales (Corti and Mills, 2006), and diversification into services (Legnani et al., 2009), was taken to indicate resilience, while growth in services revenue indicated improvements in business competitiveness.

Quantifiable performance data is elusive and too commercially sensitive for many organisations to divulge. Typically we were told 'we don't feel comfortable sharing details about this but we have seen a very significant increase in revenue as a result of us having embraced advanced services. This is a trend we are seeking to harness and continue into the future'. Where we were given evidence, we were often not permitted to publish it.

Table 3 captures the limited data that organisations were willing to share. Regarding customers, leading adopters have experienced significant cost reductions through advanced services, ranging from $25-30 \%$. Although the data points are few, there is clear indication that significant savings are possible. Likewise, while we were told of many improvements to services of customers, only Alstom Transport was able to indicate this impact by describing the change in passenger numbers on the West Coast Mainline.

Evidence is stronger for OEMs themselves. A range of companies indicated that they had either achieved, or were striving to achieve, a 50/50 split in product/ service revenues. Although it is difficult to establish the precise make-up of these service revenues, there is clear indication of a 'balanced economy' within OEMs themselves, 
which has improved their own resilience against economic downturn. As for growth, the evidence we have suggests that OEMs themselves believe they can achieve a growth in services revenue in the region of 5-10\% per year. Again, there are many caveats to this figure; the main take-away point is that growth is seen as achievable in an otherwise stagnant economic context.

\section{Business trade-offs}

The counterbalance to the benefits of offering advanced services is complex. It is all too easy to become distracted into a debate around the challenges of transforming and adopting servitization (Christensen and Raynor; and Brax, 2005). Our focus is not this change management process. Instead, our interest is in understanding the drawbacks of being successful in adopting and delivering advanced services.

For the customer, one danger is that the long term contracts associated with advanced services have the potential to disrupt innovation and technology adoption; furthermore, the number of people employed in the delivery of services can reduce, especially within customer operations. This may be a desired change, but may also inhibit adoption. For example, Alstom Transport cites Bucharest Metro, where the workforce has gone down from 1,700 to circa 850 , by moving it from public to private operation.

For OEMs themselves, conventional revenue streams are likely to reduce. Sales of spare parts will decline, and the internal consumption of spare parts (for repair and overhaul) reduces as these become a burden on the host. Alstom Power has seen its concentrated product development and support organisation shrink significantly.

In summary, through this study we now understand about benefits that:

Finding 3: Servitized manufacturers and their customers have realised the benefits they sought, and found that there are additional benefits that strengthen their competitiveness. Although elusive, there is evidence that servitization has a very positive impact on resilience, efficiencies and growth. Trade-offs are, however, inevitable as OEMs sacrifice more traditional revenue streams.

\subsection{ENABLERS AND INHIBITORS OF SERVICE ADOPTION}

Our study also explored the process of advanced services adoption. In particular: What factors are inhibiting and enabling the adoption of these services within both customers and OEMs? Table 6 summarises our findings.

\section{Inhibitors within customers}

Customers resist engaging in advanced services where they are unconvinced, uncomfortable, or unable. There are practical factors around: ease of product substitution (e.g. if it fails it can be easily replaced); availability of suppliers that can offer a sufficient range of technologies; and institutional unwillingness to engage in outsourcing-style contracts. Adoption will also be hindered where there is fear that being overly dependent on a single supplier may restrict the customer's ability to obtain value for money (both now and in the future). For example, Finning UK described how some of its customers fear that putting 'all their eggs into one basket' may restrict their ability to get best value for money, and Islington Borough Council stressed the importance of knowledge retention to enable market re-entry should this be desirable.

Even when appealing, the customer may not be able to adopt advanced services. Limiting factors exist around process compliance, budgeting systems, data systems, legislation and contracts. For instance, Heart of England NHS Foundation Trust stressed the importance of process compliance before services can be considered for outsourcing. Contract complexity can inhibit both the customer and OEM. Another factor is a lack of people with the appropriate contracting skillsets. Even when a contract is in place, there may be a reluctance to continue engagement, if the customer feels service levels are not being met or more generally that value is not being demonstrated.

\section{Enablers within customers}

Customers are enabled to adopt advanced services when they are confident of clear organisational fit, and are able to monitor value for money by being aware of their own costs, and able to benchmark the value they receive. In the case of Eon UK; 
'You're okay actually letting the manufacturer do the services for you but you want to feel confident that you're getting value for money'

Trust in the services supplier has a direct impact.

'We have to trust them that they're not just going to walk away and leave us with very little support [Heart of England NHS Foundation Trust]

'For our customer putting more trust in their client was quite a major change of culture for them which they struggled with for quite a few years before certain people recognised the benefits'. [Rolls-Royce]

\section{Inhibitors within manufacturers}

OEMs share inhibitors around contracting, finance, and data systems. Lack of skills to construct usable and reliable contracts is a major inhibitor for smaller organisations, as is lack of availability of finance from third parties to 'unlock' services contracts.

Assuming that the OEM is committed to pursuing servitization and delivering advanced services, there are also particular inhibitors that impact its ability to follow and sustain such a strategy. Linked to contracting is the lack of intellectual property within the OEM to innovate and modify its technologies to give the cost and efficiency savings.

'Sometimes our ministry tries to buy rights to IP....you'd have thought we were in a strong position. The Australian Air Force came along a bit later and actually got rights to the IP. So somehow or another our Ministry of Defence didn't do ... didn't match up to the negotiations that the Australians got.' [Marshall

Aerospace]

Skillsets in general are a major concern for OEMs.

'...if you look at where technical skill sets are developed, it's generally within a new build environment. And my concern is with manufacturing-certainly within the heavy industries-actually being minimised, then... will that know-how and know-why and capability be there to sustain service business in the longer term? Now I think if you look at the service businesses in the UK then there's still very heavy skill sets that are there from manufacturing ... My concern is, in 20 years will we still have that same capability?' [Alstom Transport]

\section{Enablers within manufacturers}

For OEMs, a principal enabler is having strong relationships with the customer. As Finning UK argued, 'having the relationship is pretty much key to our success, if not the whole of it'. Underpinning this relationship is the reputation of the equipment and organisation itself. Again, Finning UK explained that 'customers that want to deal with us know that we are backed by Caterpillar - it's a very powerful brand.'

Relationships between the supplier and its supply chain are equally important. As Finning UK put it;

'We leverage our relationship with Caterpillar, they understand that the customer is our customer, that buys through us to buy and get the Caterpillar product. So one doesn't jump in front of the other, we are very joined up with this.'

The OEM is also enabled by its capability to innovate. This is not simply a case of having a services function and a production function as part of the same organisation; internal systems have to be in place to link these capabilities. Moreover, a capability to set up and project manage a transition to advanced services is essential.

In summary, through this study we now understand about enablers and inhibitors that:

Finding 4: Servitization is enabled when OEMs are confident and capable of delivering advanced services, and their customers are confident of a clear organisational fit. However, adoption will be inhibited if the OEM is unable to deliver services, or customers are unconvinced or uncomfortable with these. 


\subsection{POTENTIAL OF SERVITIZATION TO BUSINESS AND ECONOMY}

A key question for businesses in developed economies is around the net benefit of servitization: is it going to promote growth through enhanced competitiveness? This is easier to answer at a business level than on an economy-wide level. The companies we have studied certainly indicate potential, with examples of growth ranging from $5-10 \%$ per year. This confirms previous studies which indicate a positive correlation between the adoption of servitization and growth in revenue, profits, and employment (Sawhney, 2006; Koudal, 2006; Davies et al., 2007; and Gebauer and Fleisch, 2007).

At the economic level, however, we must also take account of displacement and ripple effects. To what extent does the success of a servitized company achieve efficiencies at the cost of other (albeit less productive) businesses and employment? To what extent does the improved ability to compete globally with this business model serve to enhance wealth-creation in the UK? There is clear evidence that servitization is a response of manufacturers in advanced economies to external pressures, a way of differentiating their offering, and a way to support economic restructuring and growth. Conceptually, servitization offers an opportunity that can impact upon both national and regional growth. It moves away from reliance on simply 'selling a product' and builds on technological capabilities.

The senior executives that have participated in this study reinforce the message comprehensively:

'Britain went too far towards services, and has got to get back to manufacturing ... but the two are completely complementary in these terms. [GKN].

You've got a safer, more reliable, more economical and more environmental installed based, number one.

[MAN].

'It presents an opportunity for companies which are basically listed on the UK Stock Market to get a foothold in other markets in the world. [BAE]

Exploitation of servitization can be enhanced by industrial policy. Adoption is inhibited by a lack of awareness in OEMs and their customers. OEMs need help with the culture change, skills, contracts and financing (Table 4) that are particular to servitization, so that they can deliver services whilst building their technology innovation capabilities along the way. The government did much to stimulate the inception of servitization in the UK with large OEMs in the 1980s; there is now an opportunity for a second phase of initiatives. Actions should include:

- Improve the measurement mechanism at a micro and macro-level so that progress in the adoption of servitization can be better monitored within organisations and in the economy as a whole.

- Improve awareness of servitization amongst public servants responsible for national and regional procurement, and increase incentives for the adoption of services from OEMs (big and small).

- Encourage financial and accounting institutions to appreciate the value of services from OEMs, and aid them in finance and contracting.

- Continue to develop an engineering and technology skills base in the UK, and educate students that these skills can be exploited in the delivery of services rather than simply in production alone.

In this study we have engaged executives from a set of organisations that are significantly important to the UK economy. Across these, there is little doubt that competing through services is a vitally important concept for the future. It is not a panacea, it is not for all organisations at all times, but it is an aid to improving the commercial and environmental sustainability of the national economy. To summarise:

Finding 5: Resilience and growth in a developed economy can be positively impacted by servitization. While such economies are complex, multi-faceted and unpredictable, there is unquantifiable real revenue growth amongst OEMs that deliver services successfully. Consequently, the executives in our study see significant potential for both the regional and macro-economy if the opportunity presented by these services-focused business models can be harnessed more effectively. 
Finding 6: Exploitation is inhibited by a lack of awareness in OEMs and their customers. This innovation is fragile, language needs to coalesce, and nurturing is needed while our understanding develops. OEMs in particular need help with the culture change, skills, contracts and financing that are particular to servitization, delivering services whilst building their technology innovation capabilities along the way (Table 4).

\section{CONCLUSION}

This study has set out to build the evidence base underpinning servitization adoption. The findings so far discussed have focused on five areas: (1) servitization and advanced services; (2) transformation: stimulus, drivers and organisational change; (3) impact on the customer and manufacturer; (4) enablers and inhibitors; and (5) potential for business and the economy. Looking across these, a further two overarching insights are apparent about the transformation process in practice. First, OEMs that have been early adopters of services strategies have largely done so to protect their commercial viability (Table 1). They have also found that services enable innovations to both products and business processes that result in growth of business with both new and existing customers (Table 2). This diversification impacts their resilience (revenues from products/services are typically split 50/50) and enables overall business growth (typically $5-10 \%$, Table 3 ). Second, customers use these services to improve their financial structure, risk profile, and efficiencies around asset management (Table 1). They have also found benefits to their own growth as a consequence of improved service performance (Table 2). Leading adopters have experienced significant cost reductions (Table 3 ) and experienced business growth in their own services to their customers.

This study contributes to our understanding of servitization. The six findings summarise how transformation is seen to be taking place in practice. These have arisen from the collective experiences of 33 senior executives, in 28 different sized organisations, from a cross section of British industry. All methodologies have their limitations, but we have found this Delphi approach valuable in eliciting a rich insight into industrial practice. To extend our understanding further, we would suggest a similar approach to investigating how servitization adoption fails. Our study has exclusively targeted organisations that have succeeded with the adoption of servitization either as providers or consumers. It would be helpful to gain insights into organisations that have chosen not to take this route, and it would be valuable to know more about OEMs who have in some way failed to achieve the desired outcomes. Such knowledge would be extremely valuable to progressing the servitization debate further. Finally, our study is positioned to be UK-centric, adopting a Delphi study benefit us to capture a more in-depth view in this relatively young field. We propose future research shall recognize the heterogeneous social and organizational nature in cross-country and cross-cultural context. Therefore, our findings does not serve as universal laws to guide how organizations should adopt servitization, rather we suggests managers can learn about our findings and adapt their own experience in their local servitization adoption.

\section{References:}

Amal K. A. (2005). Using the Delphi Technique to Search for Empirical Measures of Local Planning Agency Power The Qualitative Report Volume 10 Number 4 December 2005 718-744

Auguste, B. G., Harmon, E. P. and Pandit, V. (2006). The right service strategies for product companies. McKinsey Quarterly, 1, 40.

Baines T, Lightfoot H, Whitney D and Kay JM (2009)b. "Servitized Manufacture: Practical Challenges of Delivering Integrated Products and Services", IJMechE Part B, Vol.223, 1-9

Baines, T. and Lightfoot, H. (2013). Made to Serve 'what it takes for a manufacturer to compete through servitization and Product-Service Systems', Wiley.

Baines, T. S., Lightfoot, H. W., Benedettini, O. and Kay, J. M. (2009). The servitization of manufacturing: A review of literature and reflection on future challenges. Journal of Manufacturing Technology Management, 20, 547-567.

Baines, T; Lightfoot, H; Evans, S; Neely, A; Greenough, R; Peppard, J; Roy, R; Shehab, E; Braganza, A; Tiwari, A; Alcock,J; Angus, J; Bastl, M; Cousens, A; Irving, P; Johnson, M; Kingston, J; Lockett, H; Martinez, V; Micheli, 
P; Tranfield, D; Walton, I; and Wilson, H. (2007). 'State-of-the-art in Product Service-Systems' Proc. IMechE Part B: Journal of Engineering Manufacture. Vol 221, 1543-1533

Bardecki, M. J. (1984). Participants' response to the Delphi method: An attitudinal perspective. Technological Forecasting and Social Change, 25(3), 281-292.

Bastl, M., Johnson, M., Lightfoot, H., and Evans, S. (2012). "Buyer-supplier relationships in a servitized environment: An examination with Cannon and Perreault's framework", International Journal of Operations and Production Management, Vol. 32 Iss: 6

Bowen, D., Siehl, C., Schneider, B. (1989). A framework for analyzing customer service orientations in Manufacturing, in Academy of Management Review. 14, 75-95

BRAX, S. (2005). A manufacturer becoming service provider - challenges and a paradox. Managing Service Quality, 15, 142-155.

Brecher, C., Jeschke, S., Schuh, G., Aghassi, S., Arnoscht, J., Bauhoff, F., Fuchs, S., Jooß, C., Karmann, W. O. and Kozielski, S. (2012). Integrative production technology for high-wage countries, Springer.

Boyt, T. and Harvey, M. (1997). 'Classification of Industrial Services: a model with strategic implications' Industrial Marketing Management, Vol. 26, pp. 291-300

Chesbrough, H. (2010). Open services innovation: Rethinking your business to grow and compete in a new era, John Wiley and Sons.

Cho, Y. Y., Jeong, G. H., and Kim, S. H. (1991). A Delphi technology forecasting approach using a semi-Markov concept. Technological Forecasting and Social Change, 40, 273-287.

Christensen, C. M. and Raynor, M. E. (2003). The Innovator's Solution: Creating and Sustaining Successful Growth, Harvard Business School Press.

Cohen, M., Agrawal, N. and Agrawal, V. (2006). Winning in the Aftermarket. Harvard Business Review.

Collier, D. and Meyer, S. (1998). "A service positioning matrix", International Journal of Operations and Production Management, Vol. 18, No. 12, pp. 1223-1244

Corti and Mills, (2006). "A classification of after-sales services within the capital goods industry", International Journal of Service Technology and Management

Dalkey, N., Brown, B., and Cochran, S. (1970). "Use of self-ratings to improve group estimates.” Technological Forecasting, 1_3_, 283-291.

Datta P. and Roy, R. (2011). "Operations strategy for the effective delivery of integrated industrial productservice offerings: Two exploratory defence industry case studies", International Journal of Operations and Production Management, Vol. 31 Iss: 5 pp. 579 - 603

Davies A. (2004). "Moving base into high-value integrated solutions: a value stream approach", Industrial and Corporate Change, Vol.13, No.5, pp. 727-756

Davies et al., (2006). 'Charting a path towards integrated solutions', MIT Sloan Management Review 43,7

Davies, A., Brady, T. and Hobday, M. (2006). Charting a Path Toward Integrated Solutions. MIT Sloan Management Review, 47.

Davies, A., Brady, T. and Hobday, M. (2007). Organizing for solutions: Systems seller vs. systems integrator. Industrial Marketing Management, 36, 183-193.

De Loe, R. C. (1995). Exploring complex policy questions using the policy Delphi: A multi-round, interactive survey method. Applied Geography, 15(1), 53-68.

Ferri, C. P., Prince, M., Brayne, C., Brodaty, H., Fratiglioni, L., Ganguli, M. and Scazufca, M. (2006). Global prevalence of dementia: a Delphi consensus study. The Lancet, 366(9503), 2112-2117.

Fischer, T., Gebauer, H. and Fleisch, E. (2008). Redefining product strategies in China: Overcoming barriers to enter the medium market segment. Strategic direction (Bradford, England), 24, 3.

Fischer, T., Gebauer, H., Gregory, M., Ren, G. and Fleisch, E. (2010). Exploitation or exploration in service business development?: Insights from a dynamic capabilities perspective. Journal of Service Management, 21, 591-624. 
Fischer, T., Gebauer, H., Gustaffson, A. and Witell, L. (2009). Managerial Recommendations for Service Innovations in Different Product-Service Systems. In: Sakao, T. and Lindhal, M. (eds.) Introduction to Product/Service-System Design. Springer London.

Fligstein, N. (1991). The structural transformation of American industry: An institutional account of the causes of diversification in the largest firms, 1919-1979. The new institutionalism in organizational analysis, 311.

Fontana, A., and Frey, J. H. (1994). Interviewing: The art of science. In N. K. Denzin and Y. S. Lincoln (Eds.), Handbook of qualitative research (pp. 361-376). London: Sage.

Galbraith J., (2002). “Organising to Deliver Solutions”, Organizational Dynamics, Vol. 13, No. 2, pp 194-207

Gebauer H. and Friedli T., (2005). "Behavioural implications of the transition process from products to services”, Journal of Business and Industrial Marketing, Vol.20, No. 2, pp. 70-80

Gebauer, H. and Fleisch, E. (2007). An investigation of the relationship between behavioral processes, motivation, investments in the service business and service revenue. Industrial Marketing Management, 36, 337-348.

Gebauer, H., Paiola,M. and Saccani, N. (2013). Characterizing service networks for moving from products to solutions. Industrial Marketing Management, 42, 31-46.

Hallowell and Gambatese (2010). Qualitative Research: Application of the Delphi Method to CEM research journal of construction engineering and management (C) asce / january 2010 /

Hayes, R. H. (2005). Operations, strategy, and technology: pursuing the competitive edge, Wiley.

Johnson, M. W. and Christensen, C. M. (2008). Reinventing Your Business Model. Harvard Business Review, 50-60.

Koudal, P. (2006). The service revolution in global manufacturing industries. Deloitte Research.

Legnani, E., Cavalieri, S., and Ierace, S. (2009). A framework for the configuration of after-sales service processes. Production Planning and Control, 20(2), 113-124.

Lightfoot, H. W., T. Baines, and P. Smart. "Examining the information and communication technologies enabling servitized manufacture." Proceedings of the Institution of Mechanical Engineers, Part B: Journal of Engineering Manufacture 225.10 (2011): 1964-1968.

Malleret, V. (2006). "Value creation through service offers", European Management Journal, Vol. 24, No. 1, pp. 106-116

Martinez, V., Bastl, M., Kingston, J., \& Evans, S. (2010). Challenges in transforming manufacturing organisations into product-service providers. Journal of Manufacturing Technology Management, 21(4), 449-469.

Martinez , V. and Turner, T. (2011). Designing Competitive Service Models. In: MACINTYRE, M., PARRY, G. and ANGELIS, J. (eds.) Service design and delivery. Springer.

Masser, I., and Foley, P. (1987). Delphi revisited: Expert opinion in urban analysis. Urban Studies, 24(3), 217-225.

Mathieu V., (2001). "Service strategies within the manufacturing sector: benefits, costs and partnership", International Journal of Service Industry Management, Vol. 12, No. 5, pp. 451-475

Maull, R., Smart, A., \& Liang, L. (2013). A process model of product service supply chains. Production Planning and Control, (ahead-of-print), 1-16.

McClave, J. T., and Benson, P. G. (1988). Statistics for business and economics. San Francisco: Dellen.

Miller, M. M. (1993). Enhancing regional analysis with the Delphi method. Review of Regional Studies 23(2), 191-212.

Mont, O. (2002). “Clarifying the concept of product service systems.” Journal of Cleaner Production, Vol. 10. No.3, pp.237-245

Neely, A. (2009). "Exploring the financial consequences of the servitization of manufacturing", Operations Management Research, Vol.1, No. 2 
Neu, W. A. and Brown, S. W. (2005). Forming successful business-to-business services in goods-dominant firms. Journal of Service Research, 8, 3-17.

Oliva R. and Kallenberg R., (2003) "Managing the Transition from Products to Services", International Journal of service Industry Management, Vol.14, Nio. 2, pp. 1 -10

Parente, F. J., Anderson, J. K., Myers P., and O'Brin, T. (1984). An examination of factors contributing to Delphi accuracy. Journal of Forecasting, 3(2), 173-182.

Pawar K et al., (2009). "The PSO triangle: designing product, service and organisation to create value", Journal of Operations and Production Management, 29, 5, pp468-493

Purchase, V., Mills, J. and Parry, G. (2011). A Multi-organisational Approach to Service Delivery. In: Macintyre, M., Parry, g. and Angelis, J. (eds.) Service Design and Delivery. Springer.

Reinhart W and Ulaga W, (2008). "How to Sell Services More Profitably", Harvard Business Review, may, pp92-96

Rowe, G., and Wright, G. (1999). "The Delphi technique as a forecasting tool: Issue and analysis." Int. J. Forecast., 15, 353-375.

Sakao, T. and Lindhal, M. (2009). Introduction to product/service-system design, London, Springer.

Sawhney, M., Balasubramanian, S., and Krishnan, V. V. (2003). Creating growth with services. MIT Sloan Management Review, 45(2), 34-44.

Sawhney, M. (2006). Going beyond the product. The service-dominant logic of marketing, 365-80.

Shankar, V., Berry, . L. and Dotzel, T. (2009). A practical guide to combining products and services. Harvard Business Review, 87, 94-99.

Shi, V. G., Koh, S. C. L., Baldwin J. and Cucchiella , F. (2012). Natural resource based green supply chain management. Supply Chain Management-an International Journal, 17, 54-67.

Silvestro, R. (1992). "Towards a classification of service processes", International Journal of service Industry Management, Vol.3, No. 3, pp. 62-74

Slack N., (2005). "Operations Strategy: "Will it ever realise its potential", Gestao and Producao, Vol.12, No. 3. pp. $323-332$

Smith, L., Ng, I., and Maull, R. (2012). The three value proposition cycles of equipment-based service. Production Planning and Control, 23(7), 553-570.

Sumi, T. and Kitatani, T. (2014). Trends and Issues in Service Business Innovations in Japanese Manufacturing Industry. In: Kosaka, M. and Shirahaha, K. (eds.) Progressive Trends in Knowledge and System-Based Science for Service Innovation. IGI Global.

Tukker A., (2004). "Eight Types of Product service system; Eight ways to sustainability? Experiences from SUSPRONET", Business Strategy and the Environment, Vol. 13, pp. 246 - 260

Ulaga, W. and Reinartz, W. J. (2011). Hybrid Offerings: How Manufacturing Firms Combine Goods and Services Successfully. Journal of Marketing, 75, 5-23.

Vandermerwe S. and Rada J., (1988). "Servitization of Business: Adding Value by Adding Services", European Management Journal. Vol.6, No. 4

Waissbluth, M., and De Gortari, A. (1990). A methodology for science and technology planning based upon economic scenarios and Delphi techniques. Technological Forecasting and Social Change, 37(4), 383-397.

Windahl, C., Andersson, P., Berggren, C. and Nehler, C. (2004). Manufacturing firms and integrated solutions: characteristics and implications. European Journal of Innovation Management, 7, 218-228.

Wise and Baumgartner. (1999). Harvard "Go downstream: The New Profit Imperative in Manufacturing", Business Review Sept/Oct., pp. 133 - 141

Yorozu, C. and Shi, V. G. Servitization and Japan's keiretsu organization. In: BAINES, T., ed. Spring Servitization Conference, (2014): Aston, UK. 


\begin{tabular}{|c|c|c|c|c|c|c|c|c|c|c|c|c|c|c|c|c|c|c|c|c|c|c|c|c|c|c|c|}
\hline & 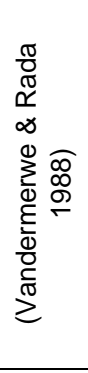 & 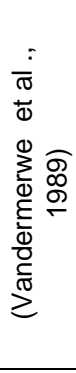 & 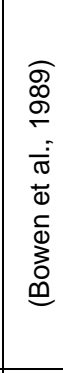 & 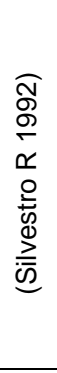 & 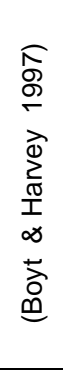 & 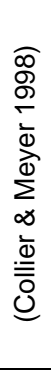 & 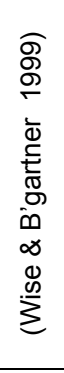 & 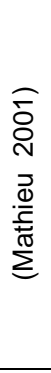 & 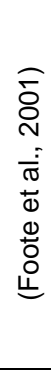 & 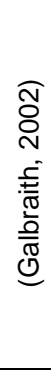 & 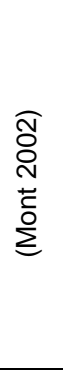 & 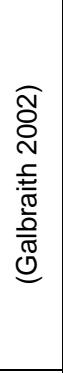 & 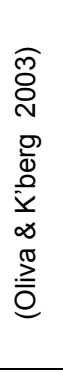 & 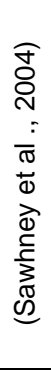 & 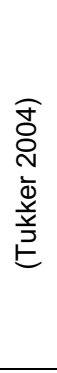 & 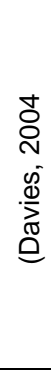 & 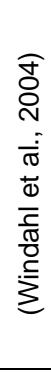 & 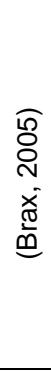 & 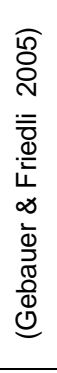 & 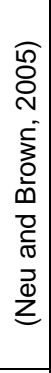 & 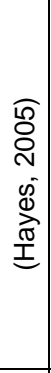 & $\begin{array}{l}\frac{1}{0} \\
\stackrel{0}{0} \\
\frac{r}{0} \\
\frac{\pi}{0}\end{array}$ & 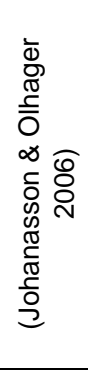 & 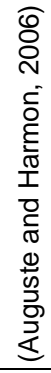 & 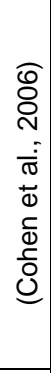 & 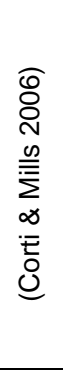 & 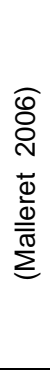 \\
\hline $\begin{array}{l}\text { What is the } \\
\text { phenomina? }\end{array}$ & & & $x$ & $x$ & $x$ & $x$ & & & & & & & $x$ & & $x$ & $x$ & & & & & & & $x$ & & $x$ & $x$ & \\
\hline $\begin{array}{l}\text { How is it adopted } \\
\text { within an } \\
\text { organisation? }\end{array}$ & $x$ & & & & & & & $x$ & $x$ & & & $x$ & & & & & & & $x$ & & $x$ & $x$ & & & $x$ & & \\
\hline $\begin{array}{l}\text { Why is it } \\
\text { adotpted? }\end{array}$ & $x$ & & & & & & $x$ & $x$ & & & $x$ & & $x$ & & $x$ & & & & $x$ & & & $x$ & & & & & $x$ \\
\hline $\begin{array}{l}\text { When does the } \\
\text { adoption occur? }\end{array}$ & $x$ & $x$ & & & $x$ & & & $x$ & & $x$ & $x$ & & $x$ & & $x$ & & $x$ & $x$ & $x$ & $x$ & & $x$ & & $x$ & & & $x$ \\
\hline $\begin{array}{l}\text { What are the } \\
\text { outcomes of } \\
\text { adoption? }\end{array}$ & & & & & & & & & & & & & & $x$ & & & & & & & & & & & & & \\
\hline
\end{tabular}

Table 1: Contributions in the transformation debate 


\begin{tabular}{|c|c|c|c|c|c|c|c|c|c|c|c|c|c|c|c|c|c|c|c|c|c|c|c|c|c|}
\hline & 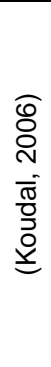 & 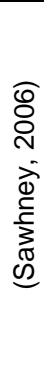 & 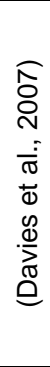 & 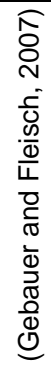 & 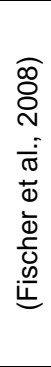 & 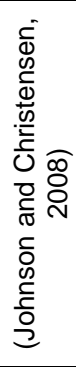 & 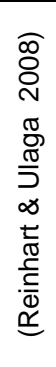 & 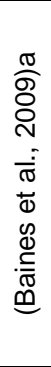 & 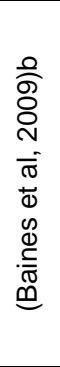 & 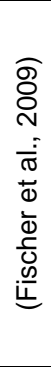 & 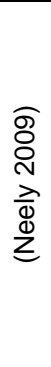 & 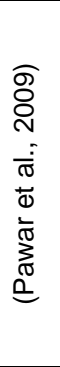 & 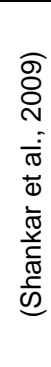 & 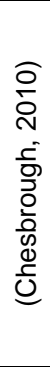 & 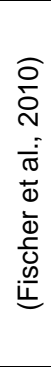 & 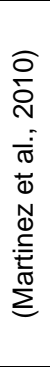 & 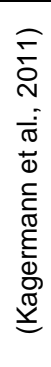 & 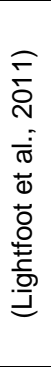 & 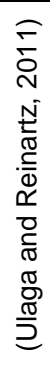 & 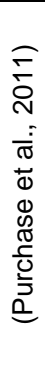 & 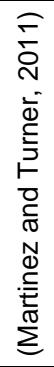 & 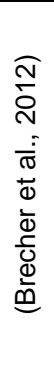 & 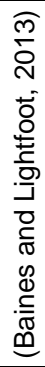 & 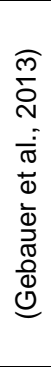 & 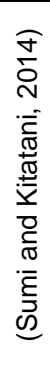 \\
\hline $\begin{array}{l}\text { What is the } \\
\text { phenomina? }\end{array}$ & $x$ & & $x$ & & & $x$ & & & & $x$ & & $x$ & $x$ & $x$ & $x$ & & & & & $x$ & $x$ & & $x$ & $x$ & $x$ \\
\hline $\begin{array}{l}\text { How is it } \\
\text { adopted } \\
\text { within an } \\
\text { organisation? }\end{array}$ & & & & & $x$ & & & & $x$ & & & & $x$ & $x$ & & $x$ & $x$ & $x$ & $x$ & $x$ & $x$ & $x$ & $x$ & & $x$ \\
\hline $\begin{array}{l}\text { Why is it } \\
\text { adotpted? }\end{array}$ & $x$ & & & & & & & $x$ & & $x$ & & & & $x$ & & & & & & & & & $x$ & & \\
\hline $\begin{array}{l}\text { When does } \\
\text { the adoption } \\
\text { occur? }\end{array}$ & $x$ & $x$ & $x$ & $x$ & & & $x$ & $x$ & & & & & & $x$ & $x$ & & & & $x$ & & & $x$ & $x$ & $x$ & \\
\hline $\begin{array}{l}\text { What are the } \\
\text { outcomes of } \\
\text { adoption? }\end{array}$ & $x$ & & $x$ & $x$ & & & & & & & $x$ & & & & $x$ & & & & & $x$ & & & & & \\
\hline
\end{tabular}

Table 1: Contributions in the transformation debate (Continued) 


\begin{tabular}{|c|c|c|}
\hline \multicolumn{2}{|c|}{ Company } & Job Title \\
\hline \multirow{11}{*}{ 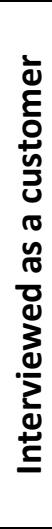 } & Boughey Distribution Services & Group Fleet Engineer \\
\hline & British Airways & Procurement Executive, Corporate Services, British Airways PLC \\
\hline & British Telecom & $\begin{array}{l}\text { Desktop Service Delivery Manager, End User Technology and } \\
\text { Security }\end{array}$ \\
\hline & British Telecom & Procurement Manager, BT Group Procurement \\
\hline & Eon UK & Plant Manager, Grain Power Station \\
\hline & GDF Suez & Manager, Deeside and Shotton Power Stations \\
\hline & Heart of England NHS Foundation Trust & Commercial \& Strategy Director \\
\hline & Hoyer & Group Board Director \\
\hline & Islington Borough Council & Head of Accommodation, Facilities and Corporate Landlord \\
\hline & Transform Sandwell & Chief Operating Officer \\
\hline & University of Nottingham & Director of Procurement \\
\hline \multirow{22}{*}{ 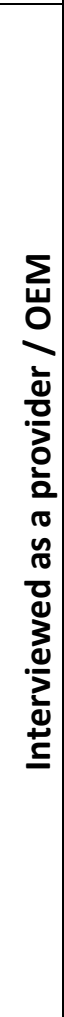 } & Alstom Power & Service Manager \\
\hline & Alstom Power & Operations Director \\
\hline & Alstom Transport & Tram Operations Director - Train Life Services, UK \& Ireland \\
\hline & Alstom Transport & Vice President- Train Life Services, UK \& Ireland \\
\hline & Babcock International & Head of Supply Chain Capability \\
\hline & BAE Systems & UK Defence Collaboration Consultant \\
\hline & Finning UK & Director of Equipment Solutions Division \\
\hline & Finning UK & General Manager Product Support Operations \\
\hline & GKN & Chief Executive, Automotive and Powder Metallurgy \\
\hline & Haigh Engineering & Managing Director \\
\hline & HCL Technologies & Director of Manufacturing Solutions \\
\hline & IBM Global Business Services & Senior Managing Consultant, Product Lifecycle Management \\
\hline & Malvern Scientific & Director \\
\hline & MAN Truck and Bus UK & Chief Executive Officer \\
\hline & MarchantCain Design & Director \\
\hline & Marshall Aerospace & Head of Commercial, Support Solutions \\
\hline & Marshall Aerospace & Managing Director, Support Solutions \\
\hline & Rolls-Royce & Head of Services Research and Development \\
\hline & Selex Electronic Systems & Head of Platform Solutions (UK) \\
\hline & $\begin{array}{l}\text { UK Council for Electronic Business } \\
\text { (UKCeB) / Rolls-Royce }\end{array}$ & Executive Director, UKCeB \\
\hline & Water Environmental Treatment & Managing Director \\
\hline & Xerox & Head of UK Marketing, Global Document Outsourcing \\
\hline
\end{tabular}

Table 2: Expert panel and associated organisation 


\begin{tabular}{|c|c|c|}
\hline & Customers & Providers (OEMs) \\
\hline 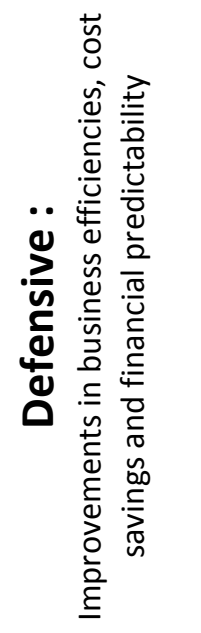 & $\begin{array}{l}\text { Seeking to improve financial, risk and asset management, } \\
\text { through: } \\
\text { - Initial cost savings } \\
\text { - On-going cost reduction } \\
\text { - Transfer of fixed costs into predictable variable costs } \\
\text { - Improved asset security } \\
\text { - Improved asset reliability }\end{array}$ & $\begin{array}{l}\text { Seeking to improve commercial viability through: } \\
\text { - Response to customer demand } \\
\text { - Competitor lock-out } \\
\text { - Smooth revenue streams } \\
\text { - Response to legislation } \\
\text { - Product life-cycle extension }\end{array}$ \\
\hline 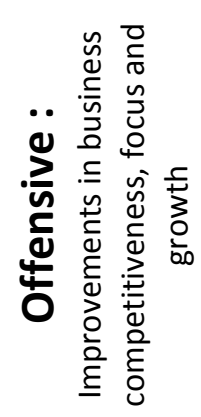 & $\begin{array}{l}\text { Seeking to Improve focus and investment through: } \\
\text { - Focus on core competences } \\
\text { - Higher capital investment } \\
\text { - Advanced technology adoption and access to } \\
\text { associated skills }\end{array}$ & $\begin{array}{l}\text { Seeking to improve growth through: } \\
\text { - Greater customer intimacy (understanding } \\
\text { - Mastomer operations / developing relationships) } \\
\text { - Market adoption of product innovations } \\
\text { - }\end{array}$ \\
\hline
\end{tabular}

Table 3: Initial drivers of service strategies 


\begin{tabular}{|c|c|c|}
\hline & Customers & Providers (OEMs) \\
\hline 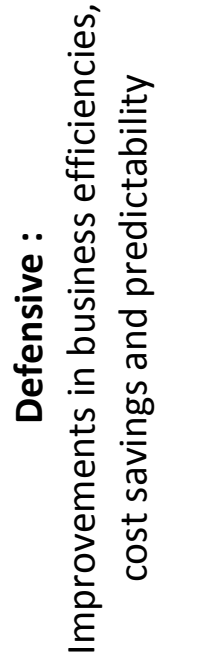 & $\begin{array}{l}\text { Improved financial, risk and asset management, through: } \\
\text { - Initial cost savings } \\
\text { - On-going cost reduction } \\
\text { - } \text { Transfer of fixed costs into predictable variable costs } \\
\text { - Improved asset security } \\
\text { - Improved asset reliability } \\
\text { Also: } \\
\text { - Improvements in safety } \\
\text { - Environmental improvements (e.g. energy } \\
\text { - } \text { Organisatiogislation) } \\
\text { - Organisal change }\end{array}$ & $\begin{array}{l}\text { Improved commercial viability through: } \\
\text { - } \text { Response to customer demand } \\
\text { - Competitor lock-out } \\
\text { - Smooth revenue streams } \\
\text { - Response to legislation } \\
\text { - Product life-cycle extension }\end{array}$ \\
\hline
\end{tabular}

Table 4: Benefits of service strategies 


\begin{tabular}{|c|c|c|}
\hline & Customers & Providers (OEMs) \\
\hline 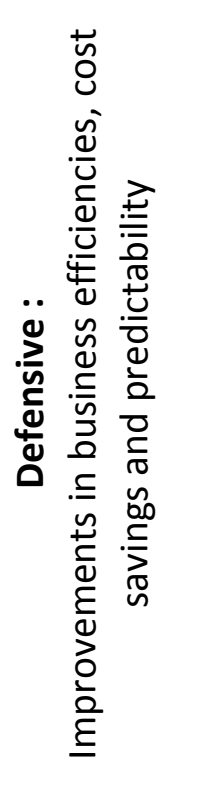 & $\begin{array}{l}\text { Cost reductions that can be attributed to advanced } \\
\text { services. } \\
\text { BA - } 30 \% \text { saving in printing and reprographic costs } \\
\text { Islington Borough Council } 28 \% \text { reduction in printing costs } \\
\text { over } 4 \text { years } \\
\text { Sandwell Borough Council } 30 \% \text { reduction in printing costs } \\
\text { over } 5 \text { years, delivered through Transform Sandwell } \\
\text { BT } 40 \% \text { saving on reprographics over } 4 \text { years } \\
\text { BAE Systems: “UK National Audit Office recognised } \\
\text { significant cost savings for MOD" }\end{array}$ & 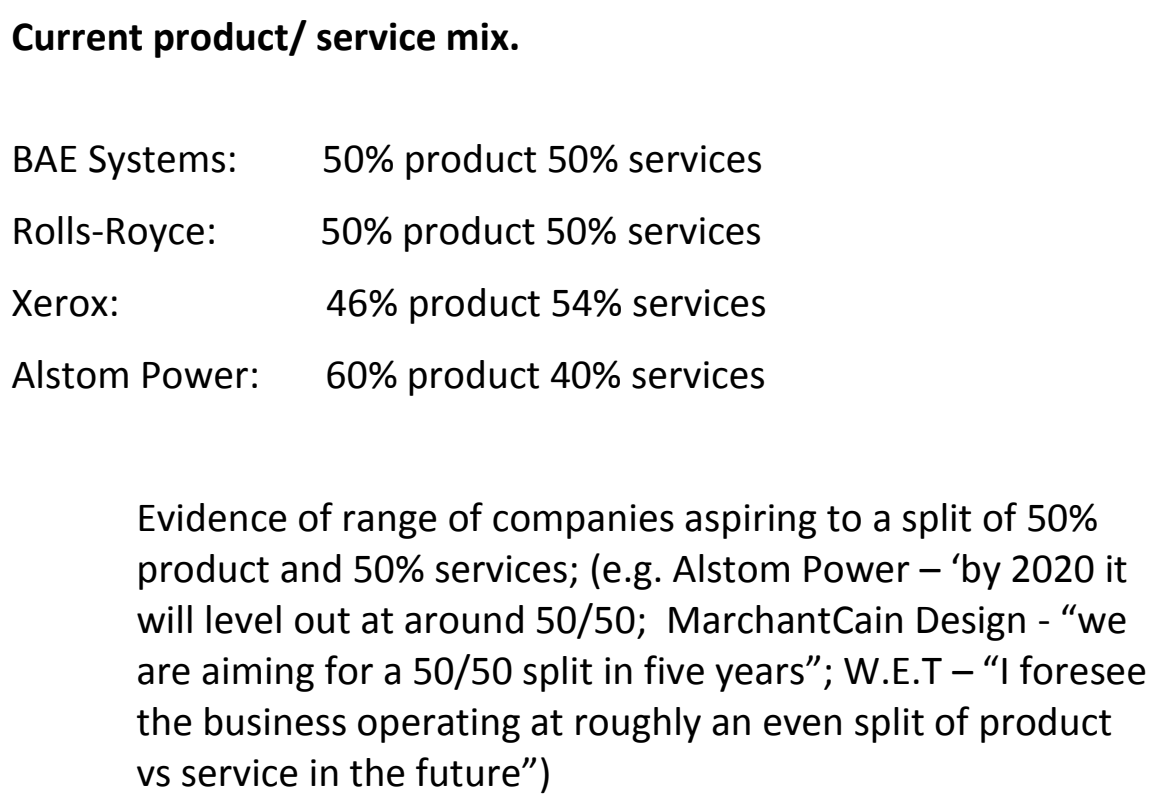 \\
\hline 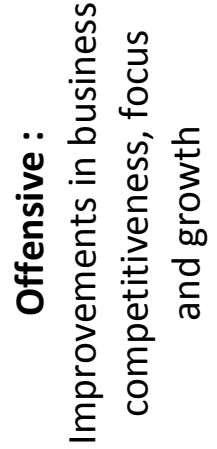 & $\begin{array}{l}\text { Business growth attributed to adoption of advanced } \\
\text { services } \\
\text { Alstom Transport: increase in passenger numbers from } 13 \\
\text { million per year to } 32 \text { million per year } \\
\text { BAE Systems: "RAF Aircraft in theatre with enhanced } \\
\text { capability" }\end{array}$ & $\begin{array}{l}\text { Business growth attributed to adoption of advanced services } \\
\text { Xerox: Last year } 6 \% \text { growth in services revenue, due to advanced } \\
\text { services, though total growth held back by decline in product sales } \\
\text { revenue; } \\
\text { IMAN predicts } 50 \% \text { growth in services in the next } 3 \text { to } 5 \text { years } \\
\text { Evidence from Alstom Energy suggests a } 9 \% \text { compound growth in } \\
\text { services over the foreseeable future. }\end{array}$ \\
\hline
\end{tabular}




\begin{tabular}{|c|c|c|}
\hline & Customers & Providers (OEMs) \\
\hline 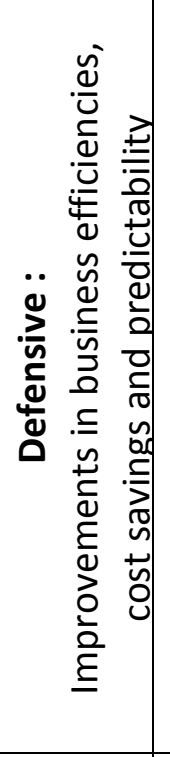 & $\begin{array}{l}\text { Customers are unconvinced, uncomfortable, or unable } \\
\text { when: } \\
\text { - Products are easily substituted } \\
\text { - Providers don't hold sufficient range of technologies } \\
\text { - There is an intuitional unwillingness to outsource } \\
\text { - Value for money is not demonstrated } \\
\text { - Technology innovations lack visibility } \\
\text { - Control is lost / being dependent is a drawback } \\
\text { - Process compliance is weak } \\
\text { - Budgeting systems lack flexibility } \\
\text { - Management information is lacking } \\
\text { - Useful and usable contracts are not available }\end{array}$ & $\begin{array}{l}\text { OEMs are unable to support services when: } \\
\text { - Useable and useful contracts are not available } \\
\text { - Financial resources for business transformation are } \\
\text { insufficient. } \\
\text { - Management information is unavailable } \\
\text { - Contract length is insufficient to recoup investment } \\
\text { - Intellectual property to support innovation is insufficient }\end{array}$ \\
\hline
\end{tabular}

